\title{
Adult literacy students' metaphors of reading and writing
}

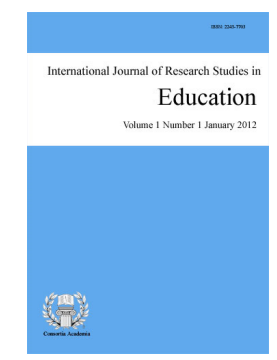

Shaw, Donita $\bowtie$

University of Kansas, USA (Donita@ku.edu)

Mahlios, Marc

University of Kansas, USA (Mahlios@ku.edu)

\section{Abstract}

The purpose of this study was to examine reading and writing metaphors of 144 adults who enrolled in literacy instruction at one of three adult education sites. Participants were given a questionnaire that solicited their metaphors for reading and writing. The adult students selected one reading metaphor from five choices or they could create their own. Likewise, they could select one of five writing metaphors or create their own. Results showed the adult students significantly differed in their reading metaphors, but they did not significantly differ in their writing metaphors. School site and age impacted their chosen reading metaphors, and gender impacted the selected writing metaphors. The most dominant reading and writing metaphor focused on parts or elements or reading and writing. Implications for adult literacy are discussed.

Keywords: adult; literacy; metaphors; reading; writing; conceptualization 


\section{Adult literacy students' metaphors of reading and writing}

\section{Introduction}

Metaphors offer a means by which humans understand life experiences and acquire new knowledge. There is a growing body of literature that supports the study and use of teachers' metaphorical images in understanding how they conceptualize their work and themselves in that work (Chen, 2003; Inbar, 1996; Martinez, Sauleda, \& Huber, 2001; Massengill, Mahlios, \& Barry, 2005; Massengill \& Mahlios, 2008; Saban, Kocbeker, \& Saban, 2007). "Metaphors may stimulate the teachers to explore new conceptual territories visible from an alternative point of view, a perspective of classroom practice which they might not have otherwise considered" (Martinez, et al., 2001, p. 974). Few studies have solicited metaphors from adult students even though students' perceptions and beliefs influence academic success (Conlon, Zimmer-Gembeck, Creed, \& Tucker, 2006; White \& Bruning, 2005), and play a role in students' persistence and retention in academic programs (Beder, 1991; Tracey-Mumford, 1994; Quigley, 1997). Therefore, the purpose of this study was to examine reading and writing metaphors of adults who enrolled in literacy instruction. The specific research questions included:

1. What patterns exist among the metaphors adult literacy students use to describe reading?

2. What patterns exist among the metaphors adult literacy students use to describe writing?

3. Are there differences among adult literacy student populations?

\section{Literature Review}

The theoretical framework for this study is based on cognitive theory. Cognitive processing theories describe how knowledge is processed, stored, and retrieved in the mind of students (Slavin, 2003). The most common is Atkinson's and Shiffrin's (1968) Information-Processing Model that describes different stages or storage systems from receiving information to retrieving information. "Information-Processing Models are illustrative of a cognitive-processing perspective because they attempt to articulate the unobservable, underlying cognitive processes" (Tracey \& Morrow, 2012, p. 153).

Metaphors are a cognitive device for learning new information, concepts, and skills, and as a means for framing and defining experience in order to achieve meaning about one's life (Hardcastle, Yamamoto, Parkay \& Chan, 1985; Yamamoto, Hardcastle, Muehl, \& Muehl, 1990). Lakoff and Johnson (1980) wrote the human conceptual system, not something humans are acutely aware of, but the part of humans that guide thought and actions, "is fundamentally metaphorical in nature" (p. 3). Metaphors help humans understand and experience something in relation to another. "Metaphors are more than literacy devices... they function as the lenses by which we perceive and conceptualize our experiences" (Norton, 1993/94, p. 1).

Literacy is conceptualized in multiple ways. When a person experiences literacy through a viewpoint or lens (or multiple ones), it allows the individual to be able to understand and communicate literacy with others (Tracey \& Morrow, 2012). Sociology, psychology, and professional education have influenced the myriad of literacy perspectives and conceptualizations (Tracey \& Morrow, 2012).

Over the past two decades researchers and teacher educators have shown considerable interest in metaphors as a means to better understand how teachers perceive their most basic views about schooling, life, children, curriculum and teaching. Sticht (1999) gave eight metaphors to 81adult educators and asked them to rank the metaphors. Results showed most instructors viewed adult literacy education as a developer of self-esteem. Additional highly-ranked metaphors were adult education as a business, investment, and public school. Mahlios and Maxson (1998) discovered four themes of teaching among pre-service teachers: teaching as telling, teaching 
Adult literacy students' metaphors of reading and writing

as nurturing, teaching as guiding, and teaching as stimulating. Differences in metaphor selection have been found between pre-service and in-service teacher beliefs (Martinez, Sauleda, \& Huber, 2001), male and female teachers (Saban, Kocbeker, \& Saban, 2007), and content area teachers (Saban, Kocbeker, \& Saban, 2007). Research on literacy metaphors of pre-service elementary teachers have identified six themes of teaching literacy, five of which connect to literacy theories (Massengill Shaw \& Mahlios, 2011). Themes of teaching that arose in previous research, specifically nurturing and guiding (Mahlios \& Maxson, 1998), were evident in the literacy metaphor responses of the population in the more recent study as well, illustrating their commonality and perhaps widespread nature.

Fewer studies have solicited metaphors of students, specifically adult students enrolled in literacy courses. Ward and Edwards (2002) interviewed 70 adults enrolled in literacy, numeracy, or English-as-a-Second-Language programs. They used the metaphor of learning as a journey to facilitate discussion between adult students and researchers. Ward and Edwards found the metaphor was an effective stimulus for discussion of the adults' reflection on their learning experiences. The metaphor empowered the learners to reflect on their academic progress and achievement of learning goals. Paulson and Armstrong (2011) solicited self-created metaphors from 128 college students enrolled in developmental literacy courses. They discovered more students viewed literacy as a product than as a process and there were 2.49 nonnegative metaphors for each negative metaphor. Sample conceptual metaphors included college reading as a journey or sport. College writing was viewed as a gaming activity or freedom of expression. The authors advocated that educators solicit students' metaphors so they can conceptually be incorporated into instruction.

We know that metaphors can be a lens for perceiving and conceptualizing experiences, including teaching and learning. Yet, minimal research has been conducted on adult students' metaphors of literacy. Therefore the purpose of this study was to examine the reading and writing metaphors of adults who attend literacy centers to determine identifiable patterns of metaphors and if metaphorical differences exist among varying adult literacy student populations.

\section{Methodology}

\subsection{Participants}

Participants in this study were 144 adults enrolled at one of three schools during spring semester 2012. Forty percent were male and 60 percent were female. The majority were in their teens (26\% were 18-19 years of age) or early twenties (33\% were 20-24 years of age). Eight percent were in their late twenties (ages 25-29), 10\% were in their $30 \mathrm{~s}, 9 \%$ in their $40 \mathrm{~s}$ and $9 \%$ in their 50 s. One person was 70 years of age. Approximately $5 \%$ chose not to reveal their age.

School 1 was a diverse community college located in a large Midwestern city that served approximately 6,000 students. All students who enrolled at the community college were tested using COMPASS (1992) to determine if they needed supportive reading classes before proceeding with their 2-year associate's degree. Forty-four students of the total population $(\mathrm{N}=144)$ for this research study were enrolled in a developmental reading support class. Their class focused on vocabulary and comprehension development, critical and analytical reading, increased reading rate and text strategies.

School 2 was a diverse, inner-city Midwestern literacy site that trained and utilized volunteers to provide individual tutoring to illiterate or functionally literate adults. Tutors had a minimum of 18 hours of training in literacy components such as phonics and word recognition, vocabulary, and comprehension strategies. Tutors met twice weekly with their adult students for an hour each time and specifically provided individual instruction in the aforementioned skill areas. Thirty of the 144 participants were from this site.

School 3 was a large, diverse adult education site in the southeastern part of the United States. This school 
offered a variety of educational opportunities (GED, certificate programs, and specific classes such as Microsoft Word) for adults at any age or academic stage. The adult education site was the sole high school diploma provider for adults in the county. Sixty-nine adults who attended the General Equivalency Degree (GED) courses participated in this metaphor research study. They were placed in a class according to their literacy level; they attended either a morning (8:00-11:30) or afternoon (1:00-4:30) session.

\subsection{Data collection}

The goal for data collection was to draw upon a previously researched questionnaire and adapt it to gather literacy data that would be efficient for an instructor to administer and collect.

We adapted an instrument titled "What Was School Like." Yamamoto and his colleagues developed the instrument through a comprehensive review of the education literature selecting constructs commonly found in the literature to describe life, schooling and children (Hardcastle, et al., 1985). The instrument has a long research history with cross-cultural populations, established content validity, and extensive research use (Hardcastle, et al., 1985; Yamamoto, et al., 1990). The life and childhood metaphors Yamamoto and his colleagues listed were replaced with literacy metaphors. To determine which literacy metaphors to list on the instrument, two prior studies were conducted. Massengill and Mahlios (2008) and Massengill Shaw and Mahlios (2001) solicited pre-service teachers' metaphors and six dominant metaphors were identified, five of which connected to literacy theories. These five literacy metaphors were then inserted into the aforementioned questionnaire.

There have been other methodologies used to allow students to express beliefs such as life-history interviews and narrative accounts (Kelchtermans, 2005); matching images of themselves with drawings of other occupations, e.g., animal keeper or entertainer (Ben-Peretz, Mendelson \& Kron, 2003); portfolio essays (Parsons, Brown \& Worley, 2004); questionnaires and surveys (Minor, Onwuegbuzie, Witcher \& James, 2002) and open-ended responses (Bozlk, 2002). Goldstein (2005) noted the difficulties some pre-service teachers may have in constructing their own metaphors and therefore suggested a procedure for providing students with a pre-selected metaphor with which to connect their nascent teaching lives. Although our population differed from pre-service teachers, the latter was the method chosen for the study reported here. There are no other known metaphor instruments in the research literature for measuring adults' metaphors of literacy.

Prior to administration of the questionnaire, the instructor (or tutor) received an explanation of the study's purpose and sample metaphors of life to explain what a metaphor is and how a metaphor of life can express one's views about life. The instructor then provided an overview of the study, obtained student permission, and discussed life metaphors with the adult students to ensure they understood metaphors. The participants were given a questionnaire with five metaphors for reading and the opportunity to create their own. Likewise, five metaphorical categories plus a create-your-own option were provided for writing. After selecting one of the five choices or creating their own metaphor for both reading and writing, students were asked to explain why they chose that metaphor. If the student had any difficulty completing the questionnaire, the instructor (or tutor) was asked to read the metaphors aloud and assist the student with stating his/her reason for each selection.

\subsection{Data analysis}

A spreadsheet was created with rows for each student and columns for each variable: adult literacy site, age, gender, reading metaphor and why, writing metaphor and why. We originally developed six age categories (ages 18-19; ages 20-24; ages 25-29; ages 30-39; ages 40-49; ages 50 and above). After running statistics and realizing that $75-80 \%$ of the age groups had a count of less than five participants, we selected to regroup participants' age into three categories: ages 18-25; ages 26-39; ages 40+. Quantitative analysis included descriptive statistics and chi-square for the variables such as age, gender, and school. Next, we employed a type case model as described by Everston, Weade, Green and Crawford (1985). We took each single case and analyzed its metaphorical 
Adult literacy students' metaphors of reading and writing

reasoning (Ball \& Smith, 1992), and then other cases were compared and contrasted. By examining each open response (why they chose the metaphor), recurrent patterns of metaphors were determined. Once patterns of reasoning were identified, the type case analysis allowed identification of what metaphors were typical or ordinary and what metaphors were atypical or extraordinary based on rationale and the frequency of occurrence.

\section{Results}

\subsection{What patterns exist among the metaphors adult literacy students use to describe reading?}

Chi-square test of independence was used to compare students' reading metaphors. This analysis showed that the students significantly differed in reading metaphors, $X^{2}(5,141)=21.43, \mathrm{p}<.001$.

\section{Table 1}

Reading metaphors

\begin{tabular}{lc}
\hline Metaphors & Percent \\
\hline Tree growing & 19.1 \\
Pieces of puzzle & 27.0 \\
Opening door & 22.0 \\
Learning to walk & 12.1 \\
Climbing a mountain & 9.2 \\
Self-created & 10.6 \\
\hline
\end{tabular}

Table 1 displays the results for metaphors of reading. As can be seen, the most selected category of reading metaphors was putting pieces of a puzzle together. An explanation written by a student is as follows. "Reading is putting together pieces of a puzzle because there are steps to reading such as learning sounds, letters, words and sentences, as compared to steps in putting a puzzle together, such as the border, then scenes." The meaning behind this metaphor was the parts or components of reading. A few students mentioned the beautiful finished product of the puzzle/story when the parts came together.

The second most common metaphor of reading was opening a door. "Reading is opening a door because reading gives you new information and knowledge which opens the door wider to opportunities in life." While the majority of open door metaphors focused on opportunities, some students also mentioned one's imagination or leaving one's environment to go on an exploration or adventure.

The third most popular metaphor was a growing tree. "Reading is a tree growing because the more one reads, the more one's comprehension and vocabulary grows as the tree brings forth more branches and leaves." Some students mentioned the time it took for a tree to grow.

More examples for each of the selected metaphors are listed in Appendix A.

Just over $10 \%$ of respondents created their own metaphor of reading. When the self-created metaphors were sorted, 12 of the 17 fell into the aforementioned categories. For example, "reading is a bird exploring new things because a bird explores new things as it soars in the air just as reading a book allows one to soar through life from the knowledge gained by reading." This would match the idea that reading is like opening a door. Another example is "reading is putting things in chronological order because it's basically building blocks to an outcome" would fit with the pieces of a puzzle emphasizing parts/components. Five self-created metaphors were unique and did not fit into any category, such as "reading is taking a nap on a cloud because reading can be very relaxing and enjoyable at times."

\subsection{What patterns exist among the metaphors adult literacy students use to describe writing?}

Chi-square test of independence was used to compare students' writing metaphors. This analysis showed 
Shaw, D. \& Mahlios, M.

that the students did not significantly differ in writing metaphors, $X^{2}(5,140)=8.63, \mathrm{p}=.125$.

Table 2

Writing metaphors

\begin{tabular}{lc}
\hline Metaphors & Percent \\
\hline Flower blossoming & 19.3 \\
Baking a cake & 22.1 \\
Following a trail & 10.0 \\
Learning to ride a bike & 16.4 \\
Running a marathon & 19.3 \\
Self-created & 12.9 \\
\hline
\end{tabular}

Table 2 displays the metaphors of writing. As can be seen, the most selected category of writing metaphors was baking a cake. The next two common metaphors tied in popularity - each received 19.3\%: writing is a flower blossoming and writing is running a marathon. Following is one example for each of these popular metaphors with more sample metaphors in Appendix B. As can be seen here, the cake metaphor focused on parts. "Writing is baking a cake because baking a cake uses many ingredients just as good writing includes many skills in order for the product to be successful." Flower metaphors focused on time to grow, beauty, or opportunity for self-expression. "Writing is a flower blossoming because writing starts with an idea and a flower starts with a seed and both continue to grow and develop to something beautiful when finished." Marathon metaphors focused on hard work, skill, and preparation. "Writing is running a marathon because becoming a good writer is a difficult process of hard work and running a marathon is a difficult task. One gets tired along the way but keeps on going and when one's finished essay is a success, it's as if you have won the marathon."

Almost $13 \%$ of the respondents self-created their own metaphor. When looking for themes, 13 of the 20 fell into the aforementioned categories. For example, "Writing is drawing a picture because writing is putting all the necessary parts in their correct place as in drawing a picture, everything has it's space" would belong with baking a cake metaphor with parts or ingredients. "Writing is following a long road that never ends because when writing you think of so much you can't stop, but unfortunately it has come to an end" would fit under following a trail metaphor. Examples from the seven that did not fit into a theme were as follows. "Writing is a rock in a garden because my spelling is so bad and I have a hard time getting through that." "Writing is the only way to a good life because without writing you can speak to people without actually saying it." "Writing is like speaking in silence because writing is a wonderful way to touch someone without saying a word."

\subsection{Are there differences among adult literacy student populations?}

Chi-square test of independence was used to compare students' reading metaphors among school, age, and gender. Chi-square indicated that the students differed in their views of reading significantly by school, $X^{2}$ $(10,141)=20.49, \mathrm{p}<.05$. They also significantly differed by age $X^{2}(10,134)=19.48, \mathrm{p}<.05$. This analysis showed that the students did not statistically differ by gender, $X^{2}(5,136)=4.78, \mathrm{p}=.44$.

When analyzing the differences we found that School 3 had the most variance. School 3 was also the largest site with multiple teachers and the greatest variety of literacy levels among students. While there was ethnic and literate diversity at each site, the population of School 1 and School 2 were more similar than School 3. Differences among age were noted as well. The younger adults (ages 18-25) were fairly even across the five reading metaphors ranging from $10-20 \%$ for each metaphor. Adults who were 40 years and older predominantly selected reading as an open door and adults ages 26-39 typically selected reading as pieces of a puzzle (46\%) or reading as learning to walk (21\%).

Chi-square test of independence was used to compare students' writing metaphors among school, age, and gender. Chi-square indicated that there were no differences among students on writing metaphors for school or age: School results were $X^{2}(10, \mathrm{~N}=140)=11.10, \mathrm{p}=.35$. Age results were $X^{2}(10, \mathrm{~N}=134)=12.61, \mathrm{p}=.25$. 
Gender differences were significant, $X^{2}(5, \mathrm{~N}=135)=12.46, \mathrm{p}<.05$.

When analyzing the gender differences, males rarely selected a flower blossoming (7\%) or following a trail (7\%). Instead males believed writing to be like baking a cake (22\%), learning to ride a bike (24\%), or running a marathon (22\%). Females predominantly chose writing as a flower blossoming (28\%), baking a cake (23\%) or running a marathon (18\%).

\section{Discussion}

The purpose of this study was to determine what metaphorical views were held by adult literacy students. This section of the paper will address three parts: discussion of the findings, conceptualizations of literacy, and implications for practice and research.

We discovered the most dominant reading and writing metaphor focused on parts: reading was putting together pieces of a puzzle, and writing was baking a cake. In the adult students' minds, they viewed reading and writing as the need to learn each part or skill, then add another part or skill and so forth until finally the process of reading and writing would be accomplished. Literature in the field supports components or parts of reading (National Reading Panel, 2000) and elements of writing (Graham \& Perin, 2007). In 2000, the National Reading Panel disseminated a report that identified five skill areas which were essential for students' development as a reader: phonemic awareness, phonics, fluency, vocabulary and text comprehension. Kruidenier (2002) looked at these components in adult education and while research was more limited, similar findings for these components were found.

Likewise, writing is a multifaceted task with multiple skills and elements coming together (Graham \& Perin, 2007). The Writing Next meta-analyses report (Graham \& Perin, 2007) identified 11 elements that were effective for writing instruction. Some of the elements include writing strategies, summarizing, collaborating, goals, prewriting, sentence combining, and the process writing approach. Since the idea of parts or elements is fairly dominant in the research, it is no surprise that previous research (Massengill \& Mahlios, 2008; Massengill Shaw \& Mahlios, 2011) identified this as a prevailing metaphor. However, it is a surprise that adult students in need of literacy instruction identified this as a dominant metaphor. We ask, "What have they experienced in their previous schooling or current instruction that created their view of reading and writing as components?" We are very curious as to what factors influenced their selection of this metaphor for both reading and writing. This will be an inquiry for a future research study.

Also of interest was the idea that students' views on writing that tied in second place were a flower blossoming and running a marathon. While gender may have played a role in this contrast, the finding tells us that writing seems to be a very well-liked or disliked skill. Research has shown that approximately $70 \%$ of students in grades 4-12 are low-achieving writers (Persky, Daane, \& Jin, 2003). For these students, writing is a challenge. Other students view writing more positively because they see it as an outlet for self-expression (Kinloch, 2011; Thomas, 2001). McBride (2000) explained how she worked with struggling and resistant students to help them find motivation for writing by focusing on writing as a channel for self-expression. McBride describes the transformation from a negative view to a positive view of writing that can occur with appropriate instructional supports.

Overall, there were some similarities between the reading and writing metaphors including the popular metaphor of parts as previously mentioned. Another example is that a similar amount (19\%) of adult students viewed reading and writing as a growing process.

In contrast, there were two categories that greatly varied in response. First, more participants viewed reading as an opportunity or exploration (22\%) than writing (10\%). This could be, in part, because when reading, the text is provided for students and reading words took their minds to various places and settings. Further, as they grew in their reading abilities more opportunities in life/work or advancing to a higher-leveled GED class opened for 
Shaw, D. \& Mahlios, M.

them. For writing, students had to create the text so it didn't allow them to mentally go to another setting and they may not have seen as much opportunity or advancement connected to their writing success. The second difference among reading and writing categories was the view of a worthwhile challenge: The number of students who viewed writing this way $(19 \%)$ was double those who viewed reading as a worthwhile challenge (9\%). This may be, in part, because of the complexity and challenge of writing (Nagin, 2003; Troia \& Graham, 2003), and the fact that while reading and writing are complementary, they also differ significantly and instruction should match the demands of each (Graham \& Perin, 2007).

There are many conceptualizations of literacy often known as lenses, viewpoints, theories or models (Tracey \& Morrow, 2012). Five conceptualizations can be matched to the literacy metaphors in this research. Table 3 aligns the metaphors with the literacy conceptualizations.

Table 3

Literacy conceptualizations and metaphors

\begin{tabular}{ll}
\hline Theories and models & Literacy metaphors \\
\hline Literacy development & Reading - tree growing \\
& Writing - flower blossoming \\
Behaviorism & Reading - pieces of a puzzle \\
& Writing - baking a cake \\
Constructivism & Reading - opening a door \\
& Writing - following a trail \\
Social learning & Reading - learning to walk \\
& Writing - learning to ride a bike \\
Cognitive processing & Reading - climbing a mountain \\
& Writing - running a marathon \\
\hline
\end{tabular}

First is literacy development. Readers and writers pass through developmental stages as they move towards proficiency. The conceptualization that reading and writing are continuous, ongoing, and gradual is best matched with the metaphors of a tree growing or a flower blossoming. Second is behaviorism. As Tracey and Morrow (2012) stated, "Behaviorism created a new perception of the task of reading as a complex act consisting of component parts" (p. 49). Literacy components such as alphabetics, fluency, vocabulary, comprehension and writing have often been incorporated into instruction as a whole. This conceptualization matches the metaphor of pieces of a puzzle and a baking a cake. Third is constructivism, which parallels the metaphors of opening a door or following a trail. As students explore during their journey, they rely on thinking and problem-solving skills and interact with people, situations, text, and information. Through these interactions they construct literacy for meaning and purpose. Fourth is social learning. Literacy does not happen in a vacuum. Language, along with learning to read and write is a social experience. Like literacy, pragmatic skills of learning to walk and learning to ride a bike are mastered through modeling by a proficient user and observation by the learner (Bandura, 1977). Finally is cognitive processing. This model explains the inner workings of the mind. This final conceptualization matches metaphors of climbing a mountain and running a marathon. Like these physically demanding tasks, reading can be mentally challenging. However, when the finish line is reached or a reader completes a book/text, it is always worth the challenge.

There are several important implications from this research. First, students have identities, stories, and personalities that need to be valued (Rogers, 2004). By giving students a voice to share their beliefs through metaphors, educators can learn about their students. When students feel valued, they become more trusting and invested in their education. Students' self-perception and agency impacts their success (Simpson \& Nist, 2002). Second, a metaphor can be an effective tool for discussions about learning progress and goals (Ward \& Edwards, 2002). It can also be an effective tool for understanding the lenses through which students see school. "The more lenses through which individuals are able to see the world, the more flexible, and ultimately capable, they can be in responding to and discussing it with others" (Tracey \& Morrow, 2012, p. xi). Third, by soliciting adult students' metaphors, we may see how their perspectives interact with dominant concepts in their literacy 
Adult literacy students' metaphors of reading and writing

program and how educators can move them forward in their literacy learning (Paulson \& Armstrong, 2011).

Metaphors give adult education leaders insights into how to improve the quality of the educational experiences and the types of supports they provide for students. Reasons students cite for discontinuing their adult educational programs can be attributed to both institutional and personal factors (Beder, 1991; Tracey-Mumford, 1994; Quigley, 1997; Zacharakis, Steichen, Diaz de Sabates, \& Glass, 2011). Understanding students' metaphors may be one avenue to increase retention; three examples follow. Students say one reason they drop-out is the lack of support during their transition from school to work/career (Zacharakis, et al., 2011). When an institution and its teachers view literacy as an open door or following a trail, they will realize the role of people helping students learn throughout one's journey. Rather than closing the door and saying goodbye and wishing students well with their newly developed skills, institutional leaders will continue to support students who transition away from their supportive environment.

Another example is personal factors that often play a critical element in students' ability to stay enrolled (Perin \& Greenberg, 1994; Taymans, Swanson, Schwarz, Gregg, Hock, \& Gerberg, 2009). If institutions/programs/instructors view literacy as a worthwhile challenge (i.e. climbing a mountain or running a marathon), they will provide support for students to work through their individual challenges, be there when they fall, and help them get back up to meet their set goal. A third example may be the institutional barrier of pedagogy or resources (Zacharakis, et al., 2011). The tree growing or flower blossoming metaphor may positively impact instruction; teachers realize the first and most important goal is to encourage students' cognitive development of reasoning and decision making regardless of curriculum or resources.

Like all research, this study has its limitations. Metaphors were collected by adult students at one point in their educational pursuit. No class discussion for their reasoning or how it relates to their current educational coursework was solicited. It would be interesting to determine if their metaphors are responsive to their situational contexts. Also, future research should triangulate data by soliciting metaphors from the instructors and adult education directors.

This research study provides rich metaphorical data from 144 students located at three adult literacy sites. By giving students opportunity to express their implicit and unconscious metaphors of literacy, the results showed which metaphors were dominant. The study also contributes to the research by identifying theories, models, and conceptualizations of literacy. Students selected metaphors, thus giving instructors insight to the learning experiences of their students.

\section{References:}

Atkinson, R. C., \& Shiffrin, R. M. (1968). Human memory: A proposed system and its control processes. In K. Spence \& J. Spence (Eds.), The psychology of learning and motivation (Vol. 2, pp. 89-195). New York: Academic Press.

Ball, M. S., \& Smith, G. W. H. (1992). Analyzing visual data. Newbury Park, CA: Sage.

Bandura, A. (1977). Social learning theory. Englewood Cliffs, NJ: Prentice Hall.

Beder, H. (1991). Adult literacy: Issues for policy and practice. Malabar, FL: Krieger.

Ben-Peretz, M., Mendelson, N., \& Kron, F. W. (2003). How teachers in different educational contexts view their roles. Teaching and Teacher Education, 19(2), 277-290. http://dx.doi.org/10.1016/S0742-051X(02)00100-2

Bozlk, M. (2002). The college student as learner: Insight gained through metaphor analysis. College Student Journal, 36(1), 142-151.

Chen, D. D. (2003). A classification system for metaphors about teaching. Journal of Physical Education, Recreation \& Dance, 74(2), 24-31. http://dx.doi.org/10.1080/07303084.2003.10608375

Conlon, E. G., Zimmer-Gembeck, M. J., Creed, P. A., \& Tucker, M. (2006). Family history, self-perceptions, attitudes and cognitive abilities are associated with early adolescent reading skills. Journal of Research 
Shaw, D. \& Mahlios, M.

in Reading, 29(1), 11-32. http://dx.doi.org/10.1111/j.1467-9817.2006.00290.x

COMPASS. (1992). American College Testing. Iowa City, IA.

Everston, C. M., Weade, R., Green, J. L., \& Crawford, J. (1985). Effective classroom management and instruction: An exploration of models. Final report. National Institute of Education Grant (NIE-G-83-0063).

Goldstein, L. S. (2005). Becoming a teacher as a hero's journey: Using metaphor in pre-service education. Teacher Education Quarterly, 32(1), 7-24.

Graham, S., \& Perin, D. (2007). Writing next: Effective strategies to improve writing of adolescents in middle and high schools - A report to Carnegie Corporation of New York. Washington, DC: Alliance for Excellent Education.

Gunning, T. G. (2010). Creating literacy instruction for all children ( $7^{\text {th }}$ ed.). Boston: Pearson Education.

Hardcastle, B., Yamamoto, K., Parkay, F. W., \& Chan, J. (1985). Metaphorical views of school: A cross-cultural comparison of college students. Teaching and Teacher Education, 1(4), 309-315. http://dx.doi.org/10.1016/0742-051X(85)90019-8

Inbar, D. (1996). The free educational prison: Metaphors and images. Educational Research, 38(1), 77-92. http://dx.doi.org/10.1080/0013188960380106

Kelchtermans, G. (2005). Teachers' emotions in educational reforms: Self-understanding, vulnerable commitment and micro political literacy. Teaching and Teacher Education, 21(8), 995-1006. http://dx.doi.org/10.1016/j.tate.2005.06.009

Kinloch, V. (2011). When it happens "across": Writing as transformative and expansive. English Journal, 100(5), 95-99.

Kruidenier, J. (2002). Research-based principles for adult basic education reading instruction. Portsmouth, NH: RMC Research Corporation.

Lakoff, G., \& Johnson, M. (1980). Metaphors we live by. Chicago: University of Chicago Press.

Mahlios, M. \& Maxson, M. (1998). Metaphors as structures for elementary and secondary pre-service teachers' thinking. International Journal of Educational Research, 29(3), 227-240. http://dx.doi.org/10.1016/S0883-0355(98)00027-5

Martinez, M. A., Sauleda, N., \& Huber, G. L. (2001). Metaphors as blueprints of thinking about teaching and learning. Teaching and Teacher Education, 17, 965-977. http://dx.doi.org/10.1016/S0742-051X(01)00043-9

Massengill, D., \& Mahlios, M. (2008). Pre-service teachers' metaphors of teaching and literacy. Reading Psychology, 29(1), 31-60. http://dx.doi.org/10.1080/02702710701568397

Massengill, D., Mahlios, M., \& Barry, A. (2005). Metaphors and sense of teaching: How these constructs influence novice teachers. Teaching Education, 16(3), 213-229. http://dx.doi.org/10.1080/10476210500204887

Massengill Shaw, D., \& Mahlios, M. (2011). Literacy metaphors of pre-service elementary teachers: Do they change after instruction? Which metaphors are stable? How do they connect to theories? Journal of Education for Teaching, 37(1), 77-92. http://dx.doi.org/10.1080/02607476.2011.538274

McBride, S. (2000). "Why are you so worried about it?" Struggles and solutions toward helping students improve as writers. English Journal, 89(6), 45-52. http://dx.doi.org/10.2307/821262

Minor, L. C., Onwuegbuzie, A. E., Witcher, A .E., \& James. T. L. (2002). Pre-service teacher's educational beliefs and their perceptions of characteristics of effective teachers. Journal of Educational Research, 96 (2), 116-127. http://dx.doi.org/10.1080/00220670209598798

Nagin, C. (2003). Because writing matters: Improving student writing in our schools. San Fracisco: Jossey-Bass. National Commission on Writing.

National Reading Panel. (2000). Report of the National Reading Panel: Reports of the subgroups. Washington, DC: National Institute of Child Health and Human Development Clearinghouse.

Norton, M. (1993-94). Of gurus, gatekeepers, and guides: Metaphors of college teaching. Teaching Excellence, 5. Ames, IA: Professional and Organizational Development Network in Higher Education.

Quigley, B. A. (1997). Rethinking literacy education: The critical need for practice-based change. San Francisco: 
Adult literacy students' metaphors of reading and writing

Jossey-Bass.

Parsons, S. C., Brown, P. U., \& Worley, V. (2004). A metaphor analysis of pre-service teachers' reflective writings about diversity. Curriculum and Teaching Dialogue, 6(1), 49-58.

Paulson, E. J., \& Armstrong, S. L. (2011). Mountains and pit bulls: Students' metaphors for college transitional reading and writing. Journal of Adolescent and Adult Literacy, 54(7), 494-503. http://dx.doi.org/10.1598/JAAL.54.7.3

Perin, D. \& Greenberg, D. (1994). Understanding dropout in an urban worker education program. Urban Education, 29(2), 169-187. http://dx.doi.org/10.1177/0042085994029002004

Persky, H. R., Daane, M. C., \& Jin,Y. (2003). The nation's report card: Writing 2002. (NCES 2003-529). U.S. Department of Education. Institute of Education Sciences. National Center for Education Statistics. Washington, DC: Government Printing Office.

Rogers, R. (2004). Storied selves: A critical discourse analysis of adult learners' literate lives. Reading Research Quarterly, 31(3), 290-305.

Saban, A., Kocbeker, B. N., \& Saban, A. (2007). Prospective teachers' conceptions of teaching and learning revealed through metaphor. Learning and Instruction, 17(2), 123-139. http://dx.doi.org/10.1016/j.learninstruc.2007.01.003

Simpson, M. L., \& Nist, S. L. (2003). An update on strategic learning: It's more than textbook reading strategies. In N. A. Stahl \& H. Boylan (Eds.), Teaching developmental reading: Historical, theoretical, and practical background readings (pp. 157-178). Boston: Bedford/St. Martin's.

Slavin, R. E. (2003). Educational psychology: Theory and practice. (7 $7^{\text {th }}$ ed.). Boston: Allyn \& Bacon.

Sticht, T. (1999). A reposting of NLA Listserv: Research Note 10/2/99. Retrieved April 4, 2012, from http://wiki.literacytent.org/index.php/Scientific-basedEdResearchPart2

Taymans, J. M., Swanson, H. L., Schwarz, R. L., Gregg, N., Hock, M., \& Gerberg, P. J. (2009). Learning to achieve. A review of the research literacy on serving adults with learning disabilities. National Institute for Literacy, Washington, DC.

Thomas, P. L. (2001). Standards, standards everywhere, and not a spot to think. English Journal, 91(1), 63-67. http://dx.doi.org/10.2307/821656

Tracey, D. H., \& Morrow, L. M. (2012). Lenses on reading (2nd ed.). New York: Guilford Press.

Tracy-Mumford, F. (1994). Student retention: Creating student success. Washington, DC: NAEPDC.

Troia, G. A., \& Graham, S. (2003). Effective writing instruction across the grades: What every educational consultant should know. Journal of Educational and Psychological Consultation 14(1), 75-89. http://dx.doi.org/10.1207/S1532768XJEPC1401_04

Ward, J., \& Edwards, J. (2002). Learning journeys: Learners'voices. Learners'views on progress and achievement in literacy and numeracy. Retrieved from ERIC database. (ED472126)

White, M. J., \& Bruning, R. (2005). Implicit writing beliefs and their relation to writing quality. Contemporary Educational Psychology, 30(2), 166-189. http://dx.doi.org/10.1016/j.cedpsych.2004.07.002

Yamamoto, K., Hardcastle, B., Muehl, S., \& Muehl, L. (1990). Metaphorical images of life in young and middle adulthood: An exploration. The Journal of Psychology, 124(2), 143-154. http://dx.doi.org/10.1080/00223980.1990.10543211

Zacharakis, J., Steichen, M., Diaz de Sabates, G., \& Glass, D. (2011). Understanding the experiences of adult learners: Content analysis of focus group data. Adult Basic Education \& Literacy Journal, 5(2), 84-95. 
Shaw, D. \& Mahlios, M.

Appendix A - Sample Metaphors of Reading

\section{Tree growing}

Reading is a tree growing because reading allows one to grow quickly in knowledge just as a young tree grows so rapidly with new leaves.

Reading is a tree growing because it takes a long time for a tree to grow and it takes a long time to become a strong reader.

\section{Pieces of a puzzle}

Reading is putting together pieces of a puzzle because as the story opens and describes the scene and characters, it puts all the pieces together that complete the authors ideas.

Reading is putting together pieces of a puzzle because if you have a puzzle piece and it look like it's going to fit but it don't you have to look at all the pieces and finds what piece best fit in that spot just like reading if you stumble over the word you have to sound it out and read over it and get that concept of the story.

\section{Opening a door}

Reading is opening a door because reading is a way of letting you understand what is going on in the world beyond your door of environment.

Reading is opening a door because reading allows a person's imagination to open the mind and take you wherever the door of the story opens up to.

\section{Learning to walk}

Reading is learning to walk because when you first learn to read you sound out alphabetics or words for the first time it is enjoyable to learn something new each day of the week. It just like learning to walk for the first time take your steps.

Reading is learning to walk because I can take it one step at a time starting at the bottom and climb to the top.

\section{Climbing a mountain}

Reading is climbing a mountain because at times reading is hard and you have to stop and rest; then you start again and it's like that until you get to the top.

Reading is climbing a mountain because reading is a work in progress as is climbing a mountain, keeping on until you succeed. 
Appendix B - Sample Metaphors of Writing

\section{Flower blossoming}

Writing is a flower blossoming because writing is a process of telling a story from the beginning to the end like a flower blooming - gradually opening up petal by petal.

Writing is a flower blossoming because writing allows you to not only express yourself but also to grow as a person, learning who are inside, as a flower blossoms and expresses itself from the inside showing it's beauty.

\section{Baking a cake}

Writing is baking a cake because you have to follow instructions.

Writing is baking a cake because it takes many steps to write a good essay like it takes many steps to bake a good cake.

\section{$\underline{\text { Following a trail }}$}

Writing is following a trail because getting one's ideas across in the right order so one can follow along and picture the scene in their mind is a thought process as is following a trail as it leads.

Writing is following a trail because you always have to stay on a steady path when writing so your reader can understand and know.

\section{Writing is learning to ride a bike}

Writing is learning to ride a bike because writing is difficult at first but with learned skills and practice one gets better and better, as learning to ride a bike is hard at first but practice and you learn the skill.

Writing is learning to ride a bike because once you have mastered writing skills, it's like riding a bike as it's something you cannot forget how to do.

\section{Writing is running a marathon}

Writing is running a marathon because running a marathon is an enduring and long event and writing is an enduring and long process.

Writing is running a marathon because there are many preparations to be ready to run a marathon as there are many skills to learn in order to write well. 
Shaw, D. \& Mahlios, M. 